\title{
RB966928 - Early maturing sugarcane cultivar
}

\author{
Edelclaiton Daros ${ }^{1}$, João Carlos Bespalhok Filho ${ }^{1 *}$, José Luis Camargo Zambon ${ }^{1}$, Oswaldo Teruyo Ido ${ }^{1}$, Ricardo Augusto de
} Oliveira $^{1}$, Lucimeris Ruaro ${ }^{1}$, and Heroldo Weber ${ }^{1}$

Received 5 March 2010

Accepted 24 May 2010

ABSTRACT - RB966928 is an early to medium maturing sugarcane cultivar and in Central-Southern Brazil it is harvested between April and June; it is recommended for planting in environments with medium to high soil fertility. It stands out with a high ratoon yield and with excellent sprouting in both plant cane and ratoon cane. It is tolerant to the major diseases of economic importance of sugarcane.

Key words: Saccharum spp., selection, improvement.

\section{INTRODUCTION}

The Genetic Improvement Program of the Federal University of Paraná [PMGCA/UFPR (www.pmgca.ufpr.br)] is part of RIDESA (www.ridesa.com.br), a network of 10 public universities promoting sugarcane breeding. Among the main objectives of PMGCA/UFPR is the development of cultivars with an early maturity cycle. Such cultivars should be planted to extend the period of sugarcane harvest in Central-Southern Brazil.

RB966928 is a sugarcane (Saccharum spp.) cultivar recommended for planting in environments of medium to high fertility. The phenotypic stability for the trait tons of sugar per hectare is high, and its main characteristic is high productivity in response to environmental improvement. The recommended harvesting time for the Center-Southern region of Brazil is from the beginning to the middle of the growing season, from April to June. It has a slightly decumbent growth habit and is well-adapted to mechanical harvest.

\section{Pedigree and method for improvement}

In 1996, caryopses were obtained from a cross of cultivar RB855156 with pollen of RB815690 (Figure 1). The cross was made at the Sugarcane Flowering and Crossing Station in Serra do Ouro (lat $9^{\circ} 13^{\prime}$ S, long 3550' W, alt 450 m asl) in Murici, state of Alagoas, which belongs to the Federal University of Alagoas. In the same year, the caryopses were germinated at the Experimental Station of Araras, São Paulo (lat $22^{\circ} 18$ ' S, long $47^{\circ} 23^{\prime} \mathrm{W}$, alt $620 \mathrm{~m}$ asl) of the Federal University of São Carlos. The planting of the first stage (T1) was performed at the Experimental Station of Paranavaí, county of Paranavaí, state of Paraná (lat 23 05' S; long $52^{\circ} 271 \mathrm{~W}$; alt $503 \mathrm{~m}$ asl) also in 1996, followed by selection of ratoon cane, in 1998. In the same year, the first clonal multiplication (stage T2) was planted at the Experimental Station Paranavaí. At that time, the experimental standard cultivar RB855156 plus hundreds of clones were planted in an augmented block experiment in two 5-m furrows of each genotype. In 2000, a clone with outstanding

\footnotetext{
${ }^{1}$ Universidade Federal do Paraná, Departamento de Fitotecnia e Fitossanitarismo, Rua dos Funcionários, 1540, 80.035-050, Curitiba, PR, Brazil. *E-mail: bespa@ufpr.br.
} 


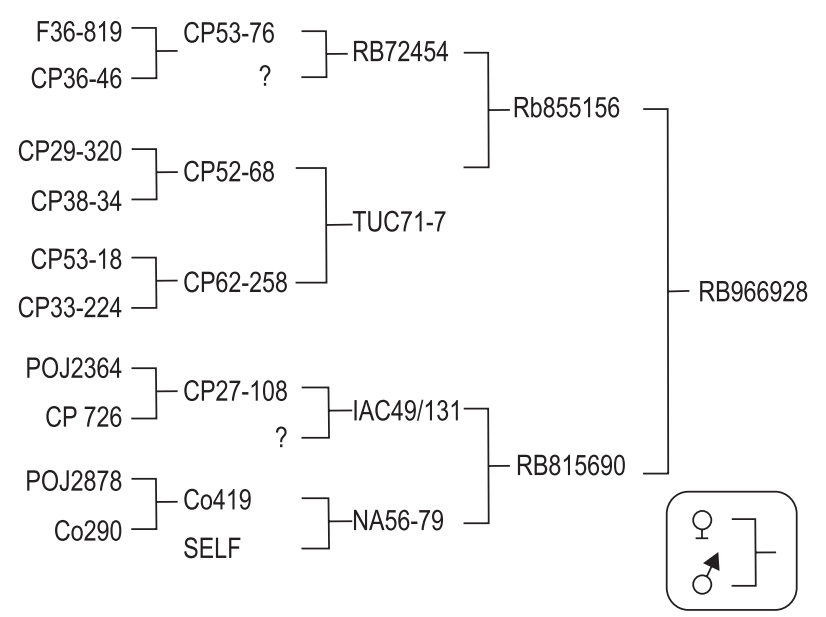

Figure 1. Pedigree of cultivar RB966928.

performance was selected and labeled RB966928. The next stage (stage T3) consisted of the evaluation and selection based on data from two growing seasons at three locations in the state of Paraná [Mandaguaçu (lat 23 $21^{\prime}$ S, long $52^{\circ}$ $05^{\prime}$ W, alt $580 \mathrm{~m}$ asl), Bandeirantes (lat $23^{\circ} 06^{\prime} \mathrm{S}$, long $50^{\circ} 22^{\prime}$ W, alt $492 \mathrm{~m}$ asl) and Paranavaí (lat $23^{\circ} 05^{\prime}$ S, long 52 $27^{\prime}$ $\mathrm{W}$, alt $503 \mathrm{~m}$ asl)], and selection was performed in 2002. In 2003, the multiplication phase was initiated and the experimental phase began in 2004, at several locations in the state of Paraná (15 sites), evaluating mainly agronomic and industrial characteristics as well as adaptability and stability in various soil-climatic regions in the North and Northwest of Paraná state (Figure 2). This phase was monitored over four growing seasons and the resistance/ tolerance to the most relevant diseases of sugarcane in

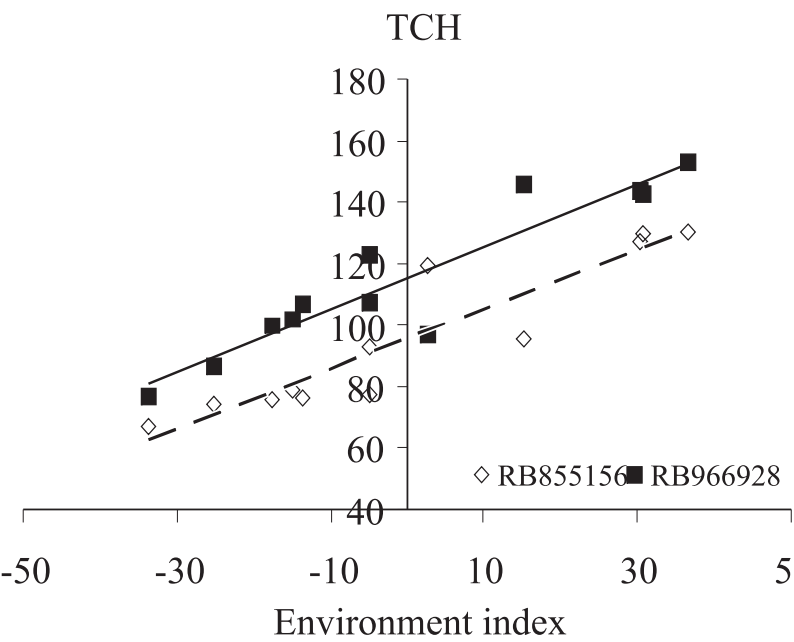

the Central-Southern region was evaluated. For the release for planting, data from 45 samples were collected between the first cut (15 samples) and the fourth cut (five samples), which confirmed the beneficial qualities of the cultivar, especially its high ratoon yield and its elevated sucrose content, as well as its general adaptability and high stability of these traits (Guerra et al. 2009).

Since 2006 when the results were corroborated in two growing seasons and in different environments in Paraná State, mills and distilleries were interested in plant propagation areas, where the cultivar RB966928 was tested under different commercial management conditions. In late 2008, in a survey conducted in Paraná, 10\% of the commercial areas were already earmarked for planting RB966928, mainly due to its earliness, yield and excellent germination in plant cane. In São Paulo state the cultivar is also widely grown, ranking among the 10 most planted cultivars in 2008 and 2009 (Chapola et al. 2009). In February 2010, the Federal University of Paraná had cultivar RB966928 protected by the National Plant Variety Protection Service, Ministry of Agriculture of Brazil.

\section{Performance}

The results based on experiments in mills and distilleries showed good performance of cultivar RB966928, especially in medium to high fertility soils, as the results obtained by the methodology of Eberhart and Russell (1966) show (Figure 2). The yield stability in different environments is high, indicating better performance than the experimental standard cultivar (RB855156). The phenotypic adaptability

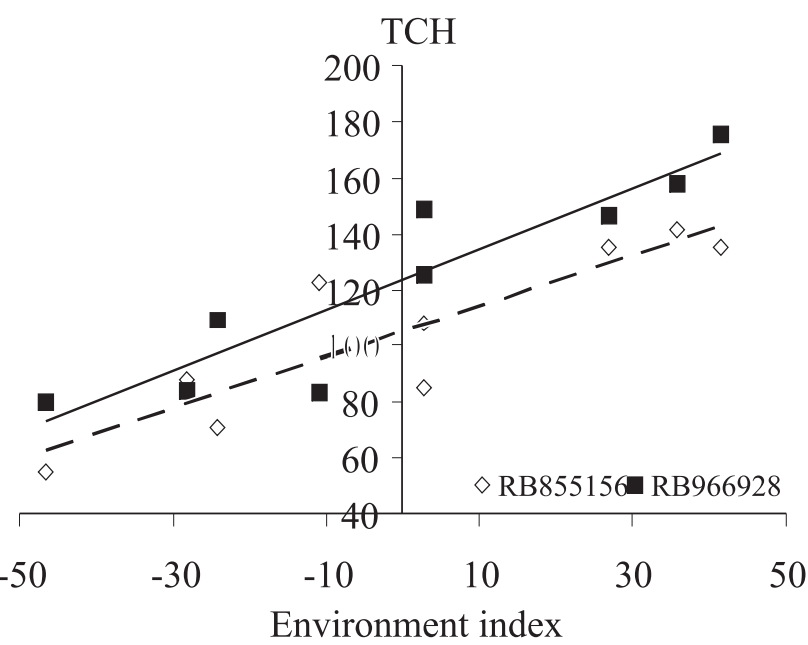

Figure 2. Phenotypic performance for cane yield ( $\mathrm{t} \mathrm{ha}^{-1}$ ) of RB966928 and RB855156 in 15 environments in plant cane and ratoon cane, Parana. 
of cultivar RB966928 was also high, indicating yield response when grown in high-fertility environments. This was observed in both the plant cane and ratoon cane cycle. It was found that the mean yield in ratoon cane was relatively higher, which was mainly due to the better rainfall distribution in the ratoon cane cycle, evidencing that environmental improvements lead to a significant yield response in cultivar RB966928. In a comparison of cv. RB966928 with the standard early maturity cultivars, cane yield was $11 \%$ higher in the mean of four cycles (Table 1). This characteristic of high agricultural yield (108.01 t ha-1) associated with the high sucrose content increases the sugar yield per area.

Table 1. Comparison of RB966928 with important early maturing cultivars in trials in Paraná, from 2003 to 2007, averaged over 15 locations

\begin{tabular}{|c|c|c|c|c|c|c|c|c|}
\hline Cultivar & $\begin{array}{c}\text { Cane yield } \\
\mathrm{th}^{-1}\end{array}$ & $(\%)^{*}$ & $\begin{array}{c}\text { Sugar yield } \\
\mathrm{tha}^{-1}\end{array}$ & $(\%)^{*}$ & $\begin{array}{l}\mathrm{SPC}^{* *} \\
(\%)\end{array}$ & $(\%)^{*}$ & $\begin{array}{c}\text { Fiber } \\
(\%)\end{array}$ & $(\%)^{*}$ \\
\hline \multicolumn{9}{|c|}{ Plant-cane crop: 15 harvests } \\
\hline RB855156 & 91,96 & 100 & 13.67 & 100 & 14.83 & 100 & 11.78 & 100 \\
\hline RB855453 & 93.63 & 102 & 13.58 & 99 & 14.48 & 98 & 12.68 & 108 \\
\hline RB966928 & 111.96 & 122 & 15.18 & 111 & 13.61 & 92 & 12.07 & 102 \\
\hline \multicolumn{9}{|c|}{ First-ratoon crop: 14 harvests } \\
\hline RB855156 & 91.27 & 100 & 13.80 & 100 & 15.02 & 100 & 11.43 & 100 \\
\hline RB855453 & 102.00 & 112 & 14.51 & 105 & 14.13 & 94 & 11.65 & 102 \\
\hline RB966928 & 111.72 & 122 & 15.66 & 113 & 14.13 & 94 & 10.89 & 95 \\
\hline \multicolumn{9}{|c|}{ Second-ratoon crop: 12 harvests } \\
\hline RB855156 & 81.75 & 100 & 11.79 & 100 & 14.83 & 100 & 11.73 & 100 \\
\hline RB855453 & 85.01 & 104 & 12.01 & 102 & 14.17 & 96 & 12.62 & 108 \\
\hline RB966928 & 99.05 & 121 & 13.74 & 117 & 13.98 & 94 & 11.91 & 101 \\
\hline \multicolumn{9}{|c|}{ Third-ratoon crop: 5 harvests } \\
\hline RB855156 & 97.63 & 100 & 13.82 & 100 & 14.20 & 100 & 10.68 & 100 \\
\hline RB855453 & 95.86 & 98 & 13.04 & 94 & 13.60 & 96 & 12.16 & 114 \\
\hline RB966928 & 109.32 & 112 & 14.82 & 107 & 13.63 & 96 & 11.10 & 104 \\
\hline
\end{tabular}

* Relative percentage, considering cultivar RB855156 as reference.

** SPC - Pol in juice (apparent percentage in cane juice).
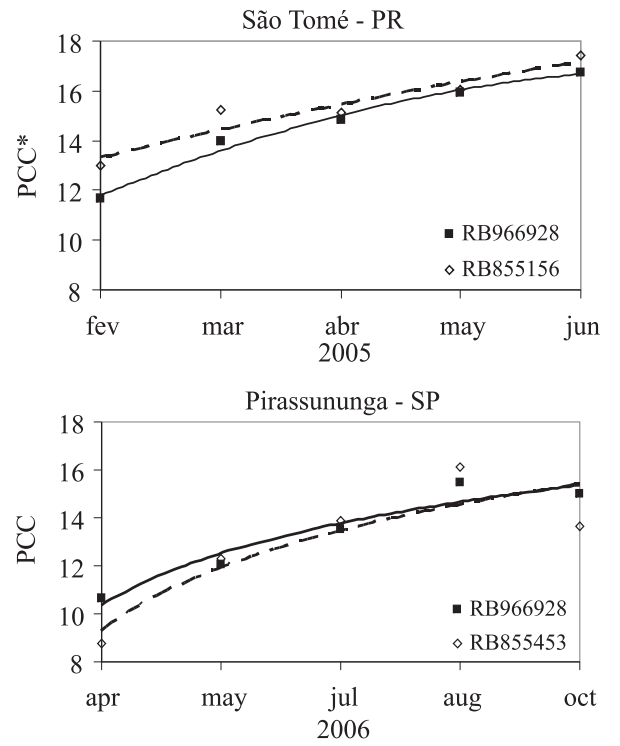

The maturity curve is represented by the accumulation of sucrose in periodic harvests. It was conducted in production areas in Paraná and São Paulo states, representing the sugarcane region of Central-Southern Brazil. The SPC (sucrose percentage in cane juice) was determined by the method described by Fernandes (2003). The maturation of RB966928 is considered early to medium, indicating the cultivar for harvest in Central-Southern Brazil from mid-April onwards (Figure 3). This cultivar represents a promising alternative for growers, who are interested in high stalk yields and sucrose content between April and June, in the Central-Southern region. It was observed that cuts after the useful period for industrialization can induce sugarcane flowering, especially in years with favorable weather for this physiological event.

The plant health of cultivar RB966928 is good; it is tolerant to brown rust (Puccinia melanocephala $\mathrm{H}$. and P. Sydow), SCMV (sugarcane mosaic virus), ScYLV (sugarcane yellow leaf virus) and leaf scald (Xanthomonas albilineans (Ashby) Dowson), and moderately tolerant to smut (Ustilago scitaminea H. and P. Sydow). However, it appears that smut incidence tends to be related to the cultivation of RB966928 in restrictive environments, not recommended for planting. Since symptoms of pokkah boeng (Fusarium moniliforme J. Sheld.) have been observed in this cultivar in disease-favorable years, the planting is not recommended in areas with a history of occurrence of this disease or in restrictive environments.
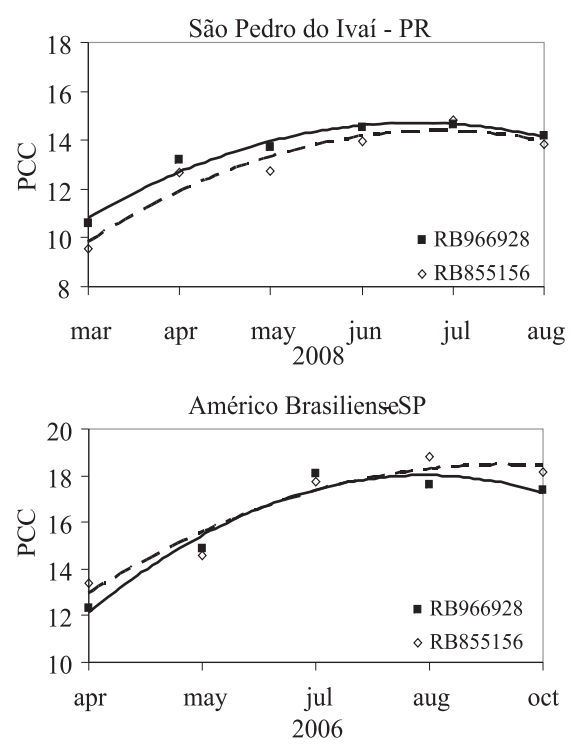

Figure 3. Maturity curves of RB966928 and other important early maturing cultivar of sugarcane used in the Center-south of Brazil at four different locations. *SPC - Pol in juice (sucrose percentage in cane juice). 


\section{Other features}

RB966928 cultivar has a slightly decumbent growth habit, with a slightly open stool, green-yellowish leaf blades, semi-open, showing a small portion of the internodes, and medium to easy straw removal, regular amount of leaves, closed canopy and short green stalk top. The medium-sized and medium diameter conoidal internodes have a circular section and are arranged in a slight zigzag, yellowish green and green-yellow when in contact with the soil, smooth, with shallow cracks and little wax. The growth ring is green-yellow, medium wide and protruding. The root region is narrow to medium wide and protruding, yellow-greenish, with abundant root primordia, with no leaf scar close to the bud insertion. Regular presence of wax in the root node region. The bud is round, little prominent, medium-sized, in touch with the growth ring, with narrow cushion, wide and medium-sized wings, and germination pore in apical position. The bud is surrounded by fine hairs; when existent, the bud furrow is shallow.

Light green, medium-long, narrow leaves, curved near the tip. Small, sickle-shaped unilateral auricle; purple-green collar dewlaps (leaf collars); short greenish sheaths, arranged in straight lines, with presence of weak to regular wax, deciduous spines in dorsal position.

\section{Seedling maintenance and distribution}

Cv RB966928 cuttings are maintained and distributed by the Department of Plant Science and Plant Health of the Federal University of Paraná, Rua dos Funcionários, 1540, Cabral, 80035-050, Curitiba, PR, Brazil.

\section{REFERENCES}

Chapola RG, Santos EGD, Rosa JRBF, Fernades AR, Bassinello AI, Vieira MAS and Hoffmann HP (2009) Censo varietal de canade-açúcar do Estado de São Paulo em 2008. Revista Stab 27: 37-39.

Eberhart SA and Russell WA (1966) Stability parameters for comparing varieties. Crop Science 6: 36-40.

Fernandes AC (2003) Cálculos na agroindústria da cana-deaçúcar. $2^{\text {th }}$ ed., EME, Piracicaba, 240p.

Guerra EP, Oliveira RA, Daros E, Zambon JLC, Ido OT and Bespalhok Filho JC (2009) Stability and adaptability of early maturing sugarcane clones by AMMI analysis. Crop Breeding and Applied Biotechnology 9: 260-267. 